\title{
Factors that Influence Young Consumer Purchasing Behaviour to Purchase Green Products through Social Media
}

\author{
Rayi Retno Dwi Asih ${ }^{1}$, Ovy Noviati Nuraini Magetsari ${ }^{2}$ \\ \{rayi@trisakti.ac.id ${ }^{1}$, ovy.magetsari@trisakti.ac.id ${ }^{2}$ \} \\ Universitas Trisakti, Jakarta Indonesia
}

\begin{abstract}
Environmentally friendly products nowadays become very important issue. It is interesting to examine how the younger generation's understandingof the factors that influence them to buy green products. Unfortunately, not all young generations intend to buy it. This research focuses on the attitude of the younger generation towards green products with the follows Attitude of young consumers, Product knowledge, Subjective norms, Perceived Behavioural Control, intention to buy, Ecolabeling, social media marketing. Researchers distributed questionnaires in a certain period of time, obtained 207 respondents, processed using the analysis tool of SEM-AMOS. The result shows that Attitude of young consumers have a positive and significant effect on the intention to buy environmentally friendly products, Product knowledge has a positive and significant effect on the attitude of young consumers, social media marketing has a positive and significant effect on subjective norms, others do not affect the intention to buy environmentally friendly products.
\end{abstract}

Keywords: Social Media Marketing; Younger Consumer; Intention to Purchase; Green Product

\section{Introduction}

Eco advancement and green buying are significant parts of improvement. Ecoadvancement centres around joining ecological manageability in each progression of the making of labour and products, prompting decreased asset utilization underway, and "offering" benefits [1], [2]. Then again, purchasing green products includes buying harmless to the ecosystem items and staying away from items that hurt the climate and creatures [3]. Green buying conduct addresses complex moral dynamic conduct and is viewed as a kind of socially mindful behaviour Individual utilization conduct has a critical adverse consequence on the climate [4]. With fast financial development and mechanical turn of events, the capacity of individual utilization has expanded extraordinarily in the days, prompting ecological decreases [4]-[6]. Related to ecological issues, the utilization of green items has turned into the focal point of customers and organizations [7], [8]. Truth be told, numerous shoppers consider natural elements when settling on utilization choices, and organizations have understood that green items have wide market possibilities, and they will advance the 
item [6], [7], [9], [10]. The Internet and data innovation have changed the climate significantly for organizations. Advertisers' new capacity to transform a wide range of correspondence into computerized media has made productive and reasonable approaches to interface organizations and purchasers and has expanded the stream and convenience of data. Organizations have the data they need to settle on more educated choices, and buyers approach more item assortment and more data about decision and quality.

This has brought about a change yet to be determined of force among purchasers and advertisers. In its endeavours to advance green items, the organization has expanded their interest in showcasing and has underlined the significance of web-based media (for example Instagram, Facebook, WeChat, Twitter and microblogs) in the advancement of green items. Online media advertising is a developing concentration for organizations to advance green items. Organizations can make the most of web freedoms to grow portion of the overall industry of items and effectively advance them via online media. Hence, comprehend the significance of online media advertising in elevating green items and to look at what webbased media promoting means for shoppers' green item buy aims. Online media promoting includes speaking with buyers through web-based media locales.

Web-based media advertising permits organizations to advance messages and make online discussions through different stages. Huge business sectors can be designated and reached through paid media, claimed media, and obtained media. Conventional paid media incorporates customary print and broadcast yet is presently joined by paid promoting on interpersonal organizations, for example, Facebook and Twitter, especially by taught youthful shoppers like understudies. Instructed youthful purchasers are picked in light of the fact that they have been observed to be more concerned and capable in regards to the climate, and backing assurance issues [11], [12]. This makes them bound to comprehend the idea and significance of economical utilization, and the effect on the climate and society [13]. Youthful customers are likewise more responsive to novel thoughts [14]. Accordingly, instructed youthful shoppers can end up being the main thrust that achieves the ideal change as far as mindful utilization designs. Moreover, youthful customers have a life expectancy that can guarantee that the progressions presented by them will remain longer, and be given to people in the future.

\section{Literature Review}

\subsection{Theory of Planned Behaviour}

The Theory of Planned Behaviour (TPB) was created from the Theory of Reasoned Action, and has been utilized widely to concentrate on social expectations and real conduct [15]-[18]. Demeanour is a general assessment of individual conduct, and is viewed as an assessment of the acquisition of harmless to the ecosystem items to anticipate harmless to the ecosystem buy conduct [15]. Past research has shown that mentality is a significant foremost factor of purchasing expectations and the more sure buyer perspectives towards harmless to the ecosystem items, the more grounded their aim to purchase; Therefore, buyers with an uplifting outlook towards harmless to the ecosystem items might be more ready to purchase these items [18]-[21].

Abstract standards are depicted as sensations of prevalent difficulty from others that exist crucial for an individual's presentation here and there, and they catch sensations of prevailing burden about a specific conduct [15]. Seen Behavioural Control alludes to the 
straightforwardness or trouble felt in performing something conduct [15]. When purchasing an eco-accommodating item, there might be a few outer elements past the singular's control, like time, value, information, and abilities.

Item Knowledge is the measure of item class data and rules put away in the memory of purchasers [22]. Item information is a significant factor impacting buyer buying perspectives towards the contribution of supportive of ecological buying conduct [23]. Web-based media promoting $(\mathrm{SMM})$ is the use of showcasing correspondence and other advertising apparatuses utilizing online media. Web-based media showcasing works with social trade, brand building, fixing the harm to a brand's standing via online media, and cultivating long haul associations with clients [24]. Online media comes into many structures, including Twitter, weblogs, and Facebook. Online media permits clients to speak with other people who share comparative interests.

Ecolabelling or ecolabeling educates shoppers about the harmless to the ecosystem qualities of the item and fabricates trust in natural cases items [25], [26]. Ecolabelling can assist advertisers with separating their contributions in the personalities of shoppers and positively affect buyer dynamic in regards to item buys, consequently expanding deals of corporate contributions [27]. It has been discovered that earth cognizant clients incline toward items marked ecolabel [28]. Past investigations have shown that ecolabels rouse customers to purchase harmless to the ecosystem items [29]-[31].

\subsection{Hypothesis Development}

Here is the advancement of the theory that was finished.

H1. There is a positive effect on buyer mentalities towards the goal to purchase. (Buy Intention) harmless to the ecosystem items.

H2. There is a positive impact of apparent conduct control (Perceived Behavioural Control) against the expectation to (Purchase Intention) harmless to the ecosystem products.

H3. There is a positive impact of ecolabelling on the goal to (Purchase Intention) harmless to the ecosystem items.

H4. There is a positive impact of emotional standards on the expectation to (Purchase Intention) harmless to the ecosystem items.

H5. There is a positive impact of item information on customer perspectives.

H6. There is an impact of web-based media showcasing on abstract standards.

\subsection{Theoretical Framework}

The theoretical structure of this concentrate as follows:

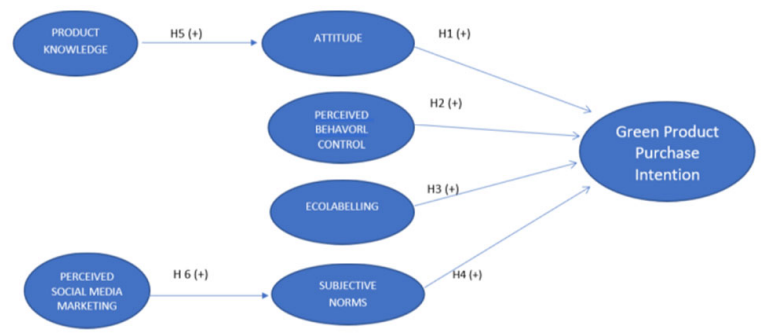

Fig. 1. Conceptual Framework 


\section{Methodology}

This review inspected Factors that impact Young Consumers' Purchasing Behaviour to purchase Green Products through Social Media. Information were gathered assortment utilizing the non-likelihood and purposive examining techniques. The rules of respondents in this review were understudies has web-based media records, and 207 of online polls were appropriated; Validity and dependability tests were directed to be analyse the instrument in the review. The consequences of the legitimacy test show that all pointers are substantial in light of the fact that they surpass the necessary worth of 0.40 . Additionally, all factors are pronounced dependable on the grounds that they surpass the Cronbach alpha worth of 0.60. After the instrument test, the model reasonableness is inspected to decide its theory utilizing the decencyof fit model, whichthought that it is qualified. Theoutcomes can be seen on table 1 .

\section{Results and Discussion}

Table 1. Instrument Test/ Data Quality

\begin{tabular}{|c|c|c|c|}
\hline Indikator & Factor Loadings & Cronbach's Alpha & Kesimpulan \\
\hline \multicolumn{4}{|c|}{ Variabel Perilaku (Attitude) } \\
\hline ATT1 & 0,845 & 0,882 & Valid dan Reliabel \\
\hline ATT2 & 0,897 & & \\
\hline ATT3 & 0,864 & & \\
\hline ATT4 & 0,851 & & \\
\hline \multicolumn{4}{|c|}{ Variabel : Persepsi Pengendalian Perilaku (Perceived Behavioral Control) } \\
\hline PBC1 & 0,822 & 0,756 & Valid dan Reliabel \\
\hline PBC2 & 0,700 & & \\
\hline PBC3 & 0,797 & & \\
\hline PBC4 & 0,857 & & \\
\hline \multicolumn{4}{|c|}{ Variabel : Ekolabel (Ecolabelling) } \\
\hline ECL1 & 0,690 & 0,682 & Valid dan Reliabel \\
\hline ECL2 & 0,722 & & \\
\hline ECL3 & 0,733 & & \\
\hline ECL4 & 0,726 & & \\
\hline \multicolumn{4}{|c|}{ Variabel : Norma Subyektif (Subjective Norms) } \\
\hline SJN1 & 0,818 & 0,817 & Valid dan Reliabel \\
\hline SJN2 & 0,887 & & \\
\hline SJN3 & 0,860 & & \\
\hline \multicolumn{4}{|c|}{ Variabel : Pengetahuan tentang Produk (Product Knowledge) } \\
\hline PDK1 & 0,858 & 0,730 & Valid dan Reliabel \\
\hline PDK2 & 0,804 & & \\
\hline PDK3 & 0,842 & & \\
\hline PDK4 & 0,839 & & \\
\hline \multicolumn{4}{|c|}{ Variabel : Pemasaran Media Sosial (Social Media Marketing) } \\
\hline SMM1 & 0,794 & 0,837 & Valid dan Reliabel \\
\hline SMM2 & 0,856 & & \\
\hline SMM3 & 0,790 & & \\
\hline SMM4 & 0,842 & & \\
\hline \multicolumn{4}{|c|}{ Variabel : Intensi (Intention) } \\
\hline INT1 & 0,774 & 0,842 & Valid dan Reliabel \\
\hline INT2 & 0,865 & & \\
\hline INT3 & 0,866 & & \\
\hline INT4 & 0,805 & & \\
\hline
\end{tabular}

Source : Data Processed 
Table 2. Gof Test (Goodness Of Fit)

\begin{tabular}{cccc}
\hline Goodness of fit index & $\begin{array}{c}\text { Hasil } \\
\text { Perhitungan }\end{array}$ & $\begin{array}{c}\text { Criteria } \\
\text { (cut-off value) }\end{array}$ & Kesimpulan \\
\hline $\mathrm{X}^{2}$ (Chi-square) & 2,751 & Diharapkan kecil & Poor Fit \\
Significance probability & 0,000 & $\geq 0,05$ & Poor Fit \\
RMSEA & 0,092 & $\leq 0,08$ & Poor Fit \\
NFI & 0,773 & $\geq 0,90$ & Poor Fit \\
RFI & 0,744 & $\geq 0,90$ & Poor Fit \\
IFI & 0,842 & $\geq 0,90$ & Marginal Fit \\
TLI & 0,820 & $\geq 0,90$ & Marginal Fit \\
CFI & 0,840 & $\geq 0,90$ & Marginal Fit \\
GFI & 0,760 & $\geq 0,90$ & Poor Fit \\
AGFI & 0,710 & $\leq$ GFI & Goodness of fit \\
\hline
\end{tabular}

Source: Data Processed

From the results of the table above it can be concluded that with various approaches used produce the conclusion of the resulting model goodness of fit because there is still one GOF Index that falls into the criteria.

\section{References}

[1] V. Veleva dan M. Ellenbecker, "Indicators of sustainable production: framework and methodology," J. Clean. Prod., vol. 9, no. 6, hlm. 519-549, 2001.

[2] M. Paradowska dan J. Platje, "European sustainable urban development policy in the light of priorities of the Europe 2020 strategy," J. Econ. Manag., vol. 19, no. 1, hlm. 95-107, 2015.

[3] A. Schaefer dan A. Crane, "Addressing sustainability and consumption," $J$. Macromarketing, vol. 25, no. 1, hlm. 76-92, 2005.

[4] J. Fan, S. Wang, Y. Wu, J. Li, dan D. Zhao, "Buffer effect and price effect of a personal carbon trading scheme," Energy, vol. 82, no. 5, hlm. 601-610, 2015.

[5] T. B. Chen dan L. T. Chai, "Attitude towards the environment and green products: Consumers' perspective," Manag. Sci. Eng., vol. 4, no. 2, hlm. 27-39, 2010.

[6] S. Lin, S. Wang, D. Marinova, D. Zhao, dan J. Hong, "Impacts of urbanization and real economic development on $\mathrm{CO} 2$ emissions in non-high income countries: empirical research based on the extended STIRPAT model," J. Clean. Prod., vol. 166, no. 2, hlm. 952-966, 2017.

[7] H. M. Gonçalves, T. F. Lourenço, dan G. M. Silva, "Green buying behavior and the theory of consumption values: a fuzzy-set approach,” J. Bus. Res., vol. 69, no. 4, hlm. 1484-1491, 2016.

[8] A. Tariq, C. Wang, Y. Tanveer, U. Akram, dan Z. Akram, "Organic food consumerism through social commerce in China," Asia Pacific J. Mark. Logist., vol. 31, no. 1, hlm. 202-222, 2019.

[9] P. Kotler, "Reinventing marketing to manage the environmental imperative," J. Mark., vol. 75 , no. 4 , hlm. 132-135, 2011.

[10] G. Akehurst, C. Afonso, dan H. M. Gonçalves, "Re-examining green purchase behavior and the green consumer profile: new evidences," Manag. Decis., vol. 50, no. 5, hlm. 972-988, 2012.

[11] S. Connell, J. Fien, J. Lee, H. Sykes, dan D. Yencken, "If it doesn't directly affect you, 
you don't think about it: a qualitative study of young people's environmental attitudes in two Australian cities," Environ. Educ. Res., vol. 5, no. 1, hlm. 95-113, 1999.

[12] M. G. Martinsons, S. K. So, C. Tin, dan D. Wong, "Hong Kong and China: emerging markets for environmental products and technologies," Long Range Plann., vol. 30, no. 2, 1997.

[13] A. Sliwka, M. Diedrich, dan M. Hofer, Citizenship Education. Munster: Waxmann Verlag, 2006.

[14] J. A. Ottman, E. R. Stafford, dan C. L. Hartman, "Avoiding green marketing myopia: ways to improve consumer appeal for environmentally preferable products," Environ. Sci. Policy Sustain. Dev., vol. 48, no. 5, hlm. 22-36, 2006.

[15] I. Ajzen, "The Theory of Planned Behavior," Organ. Behav. Hum. Decis. Process., vol. 50, hlm. 179-211, 1991, doi: https://doi.org/10.1016/0749-5978(91)90020-T.

[16] Y. Sun, S. Wang, J. Li, D. Zhao, dan J. Fan, "Understanding consumers' intention to use plastic bags: using an extended theory of planned behavior model," Nat. Hazards, vol. 89, no. 3, hlm. 1327-1342, 2017.

[17] H. Shi, S. Wang, dan D. Zhao, "Exploring urban resident's vehicular PM2. 5 reduction behavior intention: an application of the extended theory of planned behavior," $J$. Clean. Prod., vol. 147, no. 1, hlm. 603-613, 2017.

[18] S. Wang, J. Fan, D. Zhao, S. Yang, dan Y. Fu, "Predicting consumers' intention to adopt hybrid electric vehicles: using an extended version of the theory of planned behavior model," Transportation (Amst)., vol. 43, no. 1, hlm. 123-143, 2016.

[19] A. Dickinger dan M. Kleijnen, "Coupons going wireless: determinants of consumer intention to redeem mobile coupons," J. Interact. Mark., vol. 22, no. 3, hlm. 23-39, 2008.

[20] L. Han, S. Wang, D. Zhao, dan J. Li, "The intention to adopt electric vehicles: driven by functional and non-functional values," Transp. Res. Part A Policy Pract., vol. 103, no. C, hlm. 185-197, 2017.

[21] X. Ru, S. Wang, Q. Chen, dan S. Yan, "Exploring the interaction effects of norms and attitudes on green travel intention: an empirical study in eastern China," J. Clean. Prod., vol. 197, no. 2, hlm. 1317-1327, 2018.

[22] A. Philippe dan P. V. Ngobo, "Assessment of consumer knowledge and its consequences: a multi-component approach," Adv. Consum. Res., vol. 26, no. 4, hlm. 569-575, 1999.

[23] M. G. McEachern dan G. Warnaby, "Exploring the relationship between consumer knowledge and purchase behavior of value-based labels," Int. J. Consum. Stud., vol. 32, no. 5, hlm. 414-426, 2008.

[24] E. Turban, J. Outland, D. King, J. K. Lee, T.-P. Liang, dan D. C. Turban, Electronic Commerce 2018: A Managerial and Social Networks Perspective. New York: Springer, 2018.

[25] F. J. M. Rios, T. L. Martinez, F. F. Moreno, dan P. C. Soriano, "Improving attitudes toward brands with environmental associations: an experimental approach," J. Consum. Mark., vol. 23, no. 1, hlm. 26-34, 2006.

[26] Y. K. Ip, "The marketability of eco-products in China's affluent cities," Manag. Environ. Qual. An Int. J., vol. 14, no. 5, hlm. 577-589, 2003.

[27] D. Bougherara dan V. Piguet, "Market behaviour with environmental quality information costs," J. Agric. Food Ind. Organ., vol. 7, no. 2, hlm. 1-28, 2009.

[28] N. Mohan Das Gandhi, V. Selladurai, dan P. Santhi, "Unsustainable development to sustainable development: a conceptual model," Manag. Environ. Qual. An Int. J., vol. 
17, no. 6, hlm. 654-672, 2006.

[29] S. M. Harris, "Does sustainability sell? Market responses to sustainability certification," Manag. Environ. Qual. An Int. J., vol. 18, no. 1, hlm. 50-60, 2007.

[30] E. Rahbar dan N. A. Wahid, "Investigation of green marketing tools' effect on consumers' purchase behaviour,” Bus. Strateg. Ser., vol. 12, no. 2, hlm. 73-83, 2011.

[31] W. Young, K. Hwang, S. McDonald, dan C. J. Oates, "Sustainable consumption: green consumer behaviour when purchasing products," Sustain. Dev., vol. 18, no. 1, hlm. 20$31,2010$. 